\title{
THE INCIDENCE OF FREEMARTINISM IN SHEEP
}

\author{
ANNE DAIN \\ A.R.C. Institute of Animal Physiology, Babraham, Cambridge
}

(Received 27th February 1970)

\begin{abstract}
Summary. A survey of sex chimaerism in the lymphocytes of sheep twins of mixed sex was made to attempt to establish the frequency of freemartinism in sheep. The sex of the karyotype was used as a criterion. Two sets of animals with sex chimaerism were found among the 161 sets which were examined; the females were freemartins.
\end{abstract}

\section{INTRODUCTION}

The freemartin heifer, a sterile female twin to a bull calf, has been known to cattle farmers for centuries. Lillie $(1916,1917)$ and Tandler \& Keller (1911) established that the anastomosis which forms between the placentae of the twins allows hormones from the male to masculinize the indifferent gonad of the female twin. At this time, it was uncertain whether or not the condition occurred in sheep. Frazer-Roberts \& Greenwood (1928) and Ewen \& Hummason (1947) found ewes which had deformities of the genitalia like those in cattle freemartins, but did not establish that this was due to anastomosis with a male twin. In 1945, Owen found that when placental anastomosis occurs between cattle twins, the precursors of bone marrow cells are exchanged and established so that the twins show chimaerism of the erythrocytes. Anderson, Billingham, Lampkin \& Medawar (1951) showed that, in cattle, mutual skin-graft acceptance occurs not only between monozygotic but also between dizygotic twins, including those of mixed sex in which the female is a freemartin. Similar studies were made in sheep, and in 1953, Stormont, Weir \& Lane found erythrocyte chimaerism in sheep twins of mixed sex. Since the female did not breed, it was probably a freemartin. These authors estimated from their own and other data, that placental anastomosis is likely to occur in $5 \%$ of twin pregnancies and freemartinism in about $0.8 \%$ of breeding ewes, when the twinning rate is $33 \%$. Work on placental anastomosis in sheep by Petskoi (1955), Kursonov (1960) and Alexander \& Williams (1964) suggested that true vascular anastomosis of the allantoic vessels happens in $0.8 \%$ to $10 \%$ of cases but may be more frequent in inbred flocks; chorionic fusion was reported in $60 \%$ of cases. Hraba, Hasek \& Cumlivsky (1956) thought that immunological tolerance between twins should occur as often as vascular anastomosis in the chorion, but the work of Mellor (1969) shows that slight vascular anastomosis of the chorion happens in about $65 \%$ of cases, while Slee (1963) found tolerance of skin grafts between twins, in only $5 \%$ of cases. Several examples of ovine freemartins have been described (Moore \& Rowson, 1958; Slee, 1963; Alexander \& Williams, 1964; Bruere, 1966) and a large tributary connecting the umbilical arteries was shown in one 
case. So far, chimaerism of the lymphocytes does not seem to have been used as a criterion to establish the frequency of freemartinism, although it would appear to offer a precise and objective method. The present investigation is an attempt to establish whether or not this is the case.

\section{MATERIALS AND METHODS}

\section{Experimental animals}

The animals used in this survey were lambs which were born in multiple births with siblings of the opposite sex. In the 2-year duration of the survey, the numbers of the appropriate sets born in the flock at this Institute were as follows: 169 Glun Forest and Glun Forest $\times$ Hampshire, fifteen Finnish Landrace, eight Merino, six Welsh Mountain, and four Soay.

'Line breeding' is practised in the Clun Forest flock. An investigation of the breeding of twenty pairs of Clun Forest twins which were not chimaeric showed that inbreeding occurred in one out of four pedigrees, which were followed to the ggp generation. Both of the two sets of chimaeric animals had inbred pedigrees and in the case of the Merino twins G4 and G5, there was inbreeding in the gp and ggp generations.

In 1968, the lambs were examined between 3 days and 5 weeks of age. In 1969, the examination was delayed until about 3 to 6 weeks after birth. Repeat blood samples, in the case of failure of the primary culture, were obtained during the following summer, when many of the animals were several months old.

\section{Preparation of chromosome spreads}

All examinations were made on the chrcmosomes of blood lymphocytes in culture. The cultures were set up in 1-fl. oz medicine bottles by a modification of the method of Basrur \& Gilman (1964). The stain employed was $4.0 \mathrm{ml}$ Giemsa R 66 (G. T. Gurr, Ltd) with $2.0 \mathrm{ml} \mathrm{NH}{ }_{4} \mathrm{OH}\left(0.1 \mathrm{ml} 0.88 \mathrm{NH}_{4} \mathrm{OH}\right.$ in $200 \mathrm{ml}$ $\mathrm{H}_{2} \mathrm{O}$ ) and $75.0 \mathrm{ml}$ distilled water. Slides were stained for $20 \mathrm{~min}$, rinsed with distilled water and dried in the air.

The stained material was first inspected with a Wild M20 microscope, using a $\times 10$ flat-field objective, to select the most promising chromosome spreads, which were then examined with the oil immersion $\times 100$ objective when, if the chromosomes were clearly distinguishable, the sex was diagnosed. Thirty cells were selected from each animal. In twin animals in which chimaerism is clearly established, there is little difficulty in making the diagnosis. Doubt arises when only one cell, or very few cells, of the opposite sex are found in an animal. In these doubtful cases, the number of chromosomes was counted by means of the drawing tube attachment to the microscope, which projected the image of the spread onto a piece of paper. If a cell in a male animal was found to contain the modal number of chromosomes (54) but no Y chromosome, a female karyotype was recorded. On the other hand, when a single, small but poorly defined chromosome was found in a modal cell from a female animal, the ambiguity was recorded and the animal suspected of chimaerism. If one or more chromosomes were missing, no such record was made. 
Sets of triplets, in which one animal was examined, were included in the result when that animal was the only one of its sex present. In this way, the ewes were screened either in fact, or through the medium of the male sibling. The results are expressed as the percentage of ewes with sex chimaerism occurring among all the ewes born in multiple births with male siblings. In the cases of established chimaerism, fifty spreads were selected from each preparation for chromosome counts. The percentage of male and female cells was calculated on the number of modal cells present.

\section{RESULTS}

One hundred and sixty-one sets were examined. The results are set out in Table 1 and summarized in Table 2. Only two chimaeric sets were found: a Merino twin pair in 1968 and a male and female pair from Clun Forest triplets in 1969. On the basis of these results, the percentage of chimaeric females among the

TABLE 1

AN ANALYSIS OF THE INCIDENCE OF SEX CHIMAERISM IN THE TWINS, TRIPLETS AND QUADRUPLETS OF MIXED SEX BORN IN 1968 AND 1969

\begin{tabular}{|c|c|c|c|c|c|c|}
\hline & \multicolumn{2}{|c|}{ Twins } & \multicolumn{2}{|c|}{ Triplets } & \multicolumn{2}{|c|}{ Quadruplets } \\
\hline & $\begin{array}{c}\text { Complete } \\
\text { sets }\end{array}$ & $\begin{array}{c}\text { One } \\
\text { animal }\end{array}$ & $\begin{array}{c}\text { Complete } \\
\text { sets }\end{array}$ & $\begin{array}{c}\text { Two } \\
\text { animals }\end{array}$ & $\begin{array}{c}\text { Complete } \\
\text { sets }\end{array}$ & $\begin{array}{c}\text { One } \\
\text { animal }\end{array}$ \\
\hline $\begin{array}{l}1968 \\
\text { No. of sets examined } \\
\text { No. of sibling ewes examined } \\
\text { Chimaeric sets } \\
\text { Sets suspected of slight chimaerism }\end{array}$ & $\begin{array}{r}27 \\
27 \\
1 \\
5\end{array}$ & $\begin{array}{r}14 \\
14 \\
0 \\
2\end{array}$ & $\begin{array}{r}6 \\
10 \\
0 \\
1\end{array}$ & $\begin{array}{l}3 \\
3 \\
0 \\
1\end{array}$ & $\begin{array}{l}0 \\
0 \\
0 \\
0\end{array}$ & $\begin{array}{l}3 \\
3 \\
0 \\
0\end{array}$ \\
\hline $\begin{array}{l}1969 \\
\text { No. of sets examined } \\
\text { No. of sibling ewes examined } \\
\text { Chimaeric sets } \\
\text { Sets suspected of slight chimaerism }\end{array}$ & $\begin{array}{r}54 \\
54 \\
0 \\
11\end{array}$ & $\begin{array}{r}37 \\
37 \\
0 \\
3\end{array}$ & $\begin{array}{r}10 \\
13 \\
1 \\
0\end{array}$ & $\begin{array}{l}5 \\
8 \\
0 \\
0\end{array}$ & $\begin{array}{l}2 \\
4 \\
0 \\
1\end{array}$ & $\begin{array}{l}0 \\
0 \\
0 \\
0\end{array}$ \\
\hline
\end{tabular}

females of twins of mixed sex was 1-2. Table 3 shows the percentages of male and female lymphocytes in these animals. The ewe Z282 had very few of her own cells in her lymphocyte population. Neither of these ewes had bred and both had some abnormality of the external genitalia: in G5, the lips of the vulva were slightly more elongated than is usual and in Z282, which was 8 months old, one inguinal testis was palpable on the right and an enlarged clitoris was present. Both ewe lambs were poor specimens in their early months. Neither animal had yet shown signs of masculine behaviour. The chimaeric rams had both been castrated but the genitalia appeared to be normal otherwise.

In twenty-four sets of animals belonging to the whole group, a slight degree of chimaerism had been recorded which affected $13.9 \%$ of the ewes (Table 2). They were placed in this category when one or more cells of the thirty examined appeared to be of the opposite sex. Great care was taken in the sexing of the 
spreads and when there was uncertainty or when very few cells were involved, this was recorded. No animal in this category had more than five cells which were suspected of being of the opposite sex. Occasionally, only one animal of a set appeared to be affected. (It happened that the number of ewes affected or implicated by the condition in a male sibling was the same as the number of sets.) In two of these cases, Dr Elizabeth M. Tucker, at this Institute, examined the erythrocytes for chimaerism, but could not confirm it. In some cases, when successful cultures were made at a later date, chimaerism could not be found.

TABLE 2

SUMMARY: INGIDENCE OF SEX CHIMAERISM IN MULTIPLE BIRTHS OF MIXED SEX DURING 1968 AND 1969

\begin{tabular}{|c|c|c|c|c|c|c|}
\hline \multirow{2}{*}{ rear } & \multirow{2}{*}{$\begin{array}{l}\text { No. of } \\
\text { sets }\end{array}$} & \multirow{2}{*}{$\begin{array}{l}\text { No. of } \\
\text { ewes }\end{array}$} & \multicolumn{2}{|c|}{ Chimaeric ewes } & \multicolumn{2}{|c|}{$\begin{array}{c}\text { Ewes suspected } \\
\text { of slight chimaerism }\end{array}$} \\
\hline & & & No. & $\%$ & No. & $\%$ \\
\hline 1968 & 53 & 57 & 1 & $\begin{array}{c}1.8 \\
(1.75)\end{array}$ & 9 & $\begin{array}{c}15 \cdot 8 \\
(15 \cdot 80)\end{array}$ \\
\hline 1969 & 108 & 116 & 1 & $\begin{array}{c}0.9 \\
(0.86)\end{array}$ & 15 & $\begin{array}{l}12.9 \\
(12.93)\end{array}$ \\
\hline Both & 161 & 173 & 2 & $\begin{array}{l}1 \cdot 2 \\
(1 \cdot 16)\end{array}$ & 24 & $\begin{array}{l}13.9 \\
(13.87)\end{array}$ \\
\hline
\end{tabular}

TABLE 3

PERGENTAGE OF MALE AND FEMALE LYMPHOCYTES IN CHIMAERIC ANIMALS

\begin{tabular}{|c|c|c|c|c|c|c|}
\hline rear & Animal & Breed & $\begin{array}{l}\text { No. of cells } \\
\text { examined }\end{array}$ & Modal cells & \begin{tabular}{c}
$\%$ \\
Modal cells \\
\multirow{0}{*}{}
\end{tabular} & $\begin{array}{c}\text { Modal cells } \\
\text { \& }\end{array}$ \\
\hline 1968 & $\begin{array}{l}40 \\
5 \%\end{array}$ & Merino & $\begin{array}{l}50 \\
50\end{array}$ & $\begin{array}{l}74 \\
84\end{array}$ & $\begin{array}{l}40.5 \\
42.9\end{array}$ & $\begin{array}{l}59 \cdot 5 \\
57 \cdot 1\end{array}$ \\
\hline 1969 & $\begin{array}{l}\text { Z280ð } \\
\text { Z281ठ } \\
\text { Z2829 }\end{array}$ & $\begin{array}{l}\text { Clun } \\
\text { Forest }\end{array}$ & $\begin{array}{l}50 \\
50 \\
\\
50\end{array}$ & 78 & $\begin{array}{c}97 \cdot 3 \\
\text { No } \\
\text { chimaer- } \\
\text { ism } \\
93.7\end{array}$ & $\begin{array}{c}2 \cdot 7 \\
\text { No } \\
\text { chimaer- } \\
\text { ism } \\
6 \cdot 3\end{array}$ \\
\hline
\end{tabular}

\section{DISCUSSION}

Stormont et al. (1953) made an estimate of the numbers of freemartins to be expected per 100 ewes lambing in a flock with a $33 \%$ twinning rate, if placental anastomosis occurs in $5 \%$ of twin conceptuses. Their figure was $0.8 \%$ of ewes lambing. In our flock, the twinning rate for all breeds was $54 \%$, so that if placental anastomosis occurs in $5 \%$ of twins, the number of freemartins per 100 ewes lambing would be 1.35 . In fact, two freemartins were found in the offspring of 870 ewes, or 0.23 freemartins per 100 ewes lambing. Some of the blood 
cultures failed so that observations could not be made, but if the results are taken as a fair estimate, it is likely that the sort of placental anastomosis which causes freemartinism only occurs in $1.2 \%$ of twin conceptuses in this flock. It is notable that both freemartins occurred in inbred lines and that of two other freemartins which were found at the Institute in earlier years, one also had an inbred pedigree. The incidence must depend on the twinning rate in the flock and increases with increase in multiple births, but there seems to be a distinct possibility that inbreeding is the most important factor in the production of chimaerism and freemartinism. For example, Alexander \& Williams (1964) found a case of placental anastomosis after examination of only three litters from a flock which had been inbred for 80 years.

Very early stages of placental anastomosis in sheep have still to be investigated, but it may be that freemartinism and the establishment of chimaeric bone marrow depends on extremely early anastomosis, which results in the fusion of large vessels, such as that of the umbilical arteries found by Alexander \& Williams (1964) who also noticed that there was no chorionic 'suture' (Mellor, 1969) to be seen in the membranes between the two foetuses. This might be the result of very early fusion between the free-floating blastocysts instead of the more commonplace fusion which occurs when the chorionic sacs become contiguous at a later stage. In 1898, Assheton recorded his observation of a blastodermic vesicle of the sheep of the 7th day which had two germinal areas but no sign of a 'suture'. The vesicle was an abnormal shape. He suggested that the two germinal areas were the products of a single zygote, but it is possible that this structure could have come about by fusion of two separate fertilized ova as a survey of the ratio of sexes in new born lambs shows that identical twins are unlikely to be found in sheep. Such a structure as the one described by Assheton might be the requirement for established chimaerism in twins.

The confluence of minor vessels in the allantochorion, which seems to be relatively frequent (Petskoi, 1955; Kursonov, 1960; Mellor, 1969) may account for the presence of the few lymphocytes of the opposite sex in some twins of mixed sex which are examined within about 6 weeks of birth. This condition may be very different from the one which gives rise to established chimaerism. The chorion becomes completely vascular at about the 23 rd day in sheep, when the mesoblast of the somatopleure carries the allantoic vessels to the extremities of the chorion (Assheton, 1906; Perel'man, Ikonen \& Romanovskii, 1953). It is not yet known when the sheep foetus develops immune competence, but attempts to induce tolerance with donor cells at $\mathbf{5 0}$ days have failed (Moore \& Rowson, 1961). It therefore seems likely that immune reactions may develop early enough to prevent fusion of chorionic vessels on a large scale and to account for the appearance described by Mellor (1969) of the vessels of one lamb being 'repelled' from its neighbour's allantochorion.

The immune compatibility which is expected in inbred animals may account for the very early fusion of blastocysts and this could lead to the anastomosis of major vessels and the development of chimaerism. On the other hand, the reticulo-endothelial system is unformed at very early stages and this phenomenon might, therefore, take place in outbred as well as in inbred strains. Another explanation of the more frequent appearance of chimaerism in inbred flocks, is 
its control by a recessive gene. Breeding tests are being made at this Institute with a chimaeric ram (which is also a 'rig') and chimaeric female twins, to see if there is any chance of breeding chimaeric animals.

The presence of a few cells of the opposite sex in some of the twins which were examined presupposes at least a small blood vessel anastomosis between the twins, and raises the question whether, in such cases, a male twin may have a slight effect on the genital system of a female to reduce her fertility. Slee (1963) dismissed the possibility of covert freemartinism in ewes born twin to rams, when he compared the fertility of 187 ewes born twin to rams with 167 born with female twins and found no difference. In 1954, Barraclough \& Leathem showed that female mice treated with a single dose of testosterone at 5 days of age were infertile at 3 months. The fertility of mice treated at 20 days was unaffected, while those given testosterone on the 10th day had an intermediate level of fertility. If fertility in the sheep with a low level of chimaerism is completely unaffected, it may be that the anastomosis which allows this condition occurs when it is too late for the influence of male hormones to be effective.

\section{ACKNOWLEDGMENTS}

I am grateful to Dr Elizabeth M. Tucker for much helpful advice and to Professor E. C. Amoroso, F.R.s., Dr C. O. Hebb and Dr J. S. Perry for help with the manuscript. I would like to thank Miss Caroline Stephens for her able assistance in the laboratory.

\section{REFERENGES}

AleXander, G. \& Williams, D. (1964) Ovine freemartins. Nature, Lond. 201, 1296.

Anderson, D., Brllingham, R. E., Lampkin, G. H. \& Medawar, P. B. (1951) The use of skin grafting to distinguish between monozygotic and dizygotic twins in cattle. Heredity, 5, 379.

Assheton, R. (1898) An account of a blastodermic vesicle of the sheep of the seventh day, with twin germinal areas. 7. Anat. Physiol., Lond. 32, 362.

Assheton, R. (1906) The morphology of the ungulate placenta, particularly the development of that organ in the sheep, and notes upon the placenta of the elephant and hyrax. Phil. Trans. $R$. Soc. $198,143$.

Barraclough, C. A. \& Leathem, J. H. (1954) Infertility induced in mice by a single injection of testosterone propionate. Proc. Soc. exp. Biol. Med. 85, 673.

Basrur, P. K. \& GrLman, J. P. W. (1964) Blood culture method for the study of bovine chromosomes. Nature, Lond. 204, 1335.

Brugre, A. N. (1966) A study of cytogenetics in the sheep. Ph.D. thesis, University of Glasgow.

Ewen, A. H. \& Hummason, F. A. (1947) An ovine freemartin. F. Hered. 38, 149.

Frazer-Roberts, J. A. \& Greenwood, A. W. (1928) An extreme freemartin and freemartin-like condition in the sheep. F. Anat. $63,87$.

Hraba, T., HASEK, M. \& Cumlrvsky, B. (1956) Immunological approximation of sheep triplets. Natural embryonic parabionts. Folia biol., Praha, 2, 276.

Kursonov, K. M. (1960) Pseudoplacentary vascular anastomosis in embryonic parabionts and the appearance of freemartinism in sheep. Dokl. (Proc.) Acad. Sci. U.S.S.R. Biol. Sci. Section, 134, 711. (Translation).

LiLlie, F. R. (1916) The theory of the free-martin. Science, N.Y. 43,611.

LILLIE, F. R. (1917) The freemartin: a study of the action of sex hormones in the foetal life of cattle. $\mathcal{F}$. exp. Zool. 23, 371.

MELLOR, D.J. (1969) Vascular anastomosis and fusion of foetal membranes in multiple pregnancy in the sheep. Res. vet. Sci. 10, 361.

Moore, N. W. \& Rowson, L. E. A. (1958) Freemartins in sheep. Nature, Lond. 182, 1754.

Moore, N. W. \& Rowson, L. E. A. (1961) Attempts to induce tissue tolerance in sheep. Res. vet. Sci. 2,1 . 
OWEN, R. D. (1945) Immunogenetic consequences of vascular anastomosis between bovine twins. Science, N.Y. 102, 400.

Perel'man, L. R., Ikonen, M. V. \& Romanovski, N. R. (1953) Tr. Leningr. Tub. Nauchn-lssl. inst., Tub. Sbom., 325 (Quoted by Kursonov, 1960).

Petskor, P. G. (1955) Embryonic parabiosis in multiple births in agricultural animals. Proc. Severtosov. Inst. Anim. Morph. 14, 44.

SteE, J. (1963) Immunological tolerance between litter-mates in sheep. Nature, Lond. 200, 654.

Stormont, G., Weir, W. G. \& LaNe, I. L. (1953) Erythrocyte mosaicism in a pair of sheep twins. Science, N.X. 118, 695.

Tandler, J. \& Keller, K. (1911) Über das Verhalten das Chorions bei verschiedengeschlechtlicher Zwillingsgravidität des Rindes und über die Morphologie des Genitales der weiblichen Tiere, welche einer solchen Gravidität entstammer. Dt. tierärztl. Wschr. 19, 148. 